\title{
HUBUNGAN SEKTOR INFORMAL DAN PERTUMBUHAN EKONOMI DI INDONESIA
}

\section{Edvin Nur Febrianto ${ }^{1}$}

${ }^{1}$ Magister Ekonomi Kependudukan \& Ketenagakerjaan, Fakultas Ekonomi \& Bisnis, Universitas Indonesia e-mail: edvinnurfebrianto@gmail.com

\begin{abstract}
Abstrak
Determinan pertumbuhan ekonomi merupakan topik yang menarik untuk diteliti. Salah satu hal yang masih diperdebatkan antara lain hubungan antara proporsi sektor informal dengan pertumbuhan ekonomi. Penelitian ini bertujuan untuk mengkaji hubungan antara proporsi sektor informal dengan pertumbuhan ekonomi di Indonesia dengan menggunakan data Sakernas dan publikasi PDRB per provinsi yang diterbitkan BPS tahun 2005-2018. Proporsi penduduk berusia 15 tahun ke atas yang bekerja di sektor informal di setiap provinsi digunakan sebagai proksi proporsi sektor informal. Sedangkan tingkat pertumbuhan PDRB tiap provinsi digunakan sebagai proksi pertumbuhan ekonomi. Berdasarkan diagram pencar dan koefisien regresi, dapat disimpulkan bahwa hubungan antara proporsi sektor informal dan pertumbuhan ekonomi berbentuk huruf U di wilayah Indonesia bagian barat dan berbentuk huruf $U$ terbalik pada Indonesia bagian timur.
\end{abstract}

Kata Kunci: sektor informal, pertumbuhan ekonomi, huruf U terbalik, Sakernas, PDRB.

\section{PENDAHULUAN}

Definisi sektor informal menurut De Soto (1989) dan Portes et al. (1989) adalah suatu unit ekonomi yang tidak terkena aturan hukum dan pengenaan pajak dari pemerintah. Definisi tersebut sejalan dengan definisi sektor informal menurut resolusi International Conference of Labour Statisticians (ICLS) ke-17, yaitu unit-unit yang terlibat dalam produksi barang atau jasa dengan tujuan utama menciptakan lapangan pekerjaan dan pendapatan yang biasanya beroperasi dengan organisasi tingkat rendah atau dalam skala kecil, dengan sedikit atau tanpa pembedaan yang jelas antara tenaga kerja dan modal usaha sebagai faktor produksi. Status tenaga kerja sebagian besar berupa pekerja tidak tetap atau pekerja keluarga dan hubungan majikan-pekerja lebih kepada hubungan pribadi dan hubungan sosial daripada hubungan ketenagakerjaan dengan perjanjian dan/atau jaminan resmi (ILO, 2004). Sedangkan ciri-ciri pekerja informal adalah hubungan kerja yang ada tidak tunduk pada undangundang tenaga kerja, tidak dikenakan pajak pendapatan, minimnya perlindungan sosial atau hak tertentu untuk jaminan kerja. Pitoyo (2007) menyebutkan bahwa sektor informal masih identik dengan aktivitas ekonomi yang mempunyai skala kecil dan tidak efisein (kurang produktif). Bagi penduduk dengan tingkat pendidikan dan keterampilan rendah sektor informal merupakan salah satu sumber pendapatan disaat pekerjaan di sektor formal tidak bisa mereka raih.

Porta dan Shleifer (2008) menjabarkan tiga sudut pandang terhadap sektor informal. Pertama, sektor informal merupakan respon dari ketidakmerataan hak atas kepemilikan properti serta akibat dari ketidakadilan peraturan dan hukum. Kedua, sektor informal adalah salah satu bentuk upaya untuk menghindari pajak. Pada perpektif ini, sektor informal dianggap mempunyai efek negatif terhadap pertumbuhan ekonomi. Hal ini disebabkan karena peningkatan sektor informal dapat menurunkan penerimaan pajak negara sehingga pengeluaran pemerintah akan menurun. Ketiga, sektor formal dan informal independen satu sama lain dimana masing-masing mempunyai produsen dan konsumen yang bekerja dengan mekanisme yang berbeda sehingga perubahan pada sektor formal (misalnya dalam hal pajak) tidak berpengaruh terhadap sektor informal. Pada perspektif tersebut, sektor informal merupakan arena untuk penduduk miskin sehingga akan berkurang atau bahkan menghilang seiring dengan perbaikan perekonomian. 
Tabel 1. Proporsi Lapangan Kerja Informal Sektor Non-Pertanian (\%)

\begin{tabular}{|l|c|c|c|c|}
\hline \multirow{2}{*}{ Provinsi } & \multicolumn{4}{|c|}{ Tahun } \\
\cline { 2 - 5 } & 2015 & 2016 & 2017 & 2018 \\
\hline Sumatera Barat & 50,48 & 48,31 & 50,48 & 51,26 \\
\hline Dki Jakarta & 26,95 & 31,12 & 28,41 & 30,12 \\
\hline Jawa Timur & 47,9 & 45,84 & 47,34 & 47,68 \\
\hline Bali & 41,41 & 44,02 & 39,26 & 38,62 \\
\hline Kalimantan Selatan & 44,8 & 48,4 & 47,66 & 46,17 \\
\hline Sulawesi Selatan & 42,1 & 46,69 & 42,79 & 44,77 \\
\hline Maluku & 45,48 & 44,15 & 44,18 & 48,17 \\
\hline Papua & 34,57 & 39,18 & 33,8 & 34,19 \\
\hline INDONESIA & 43,37 & 43,09 & 43,75 & 44,13 \\
\hline
\end{tabular}

Sumber: BPS, 2019 (diolah)

Walaupun merupakan karakteristik dari negara berkembang, sektor informal terdapat di setiap negara di seluruh dunia baik negara maju maupun negara berkembang. Berdasarkan data yang diperoleh dari Badan Pusat Statistik (BPS), diketahui bahwa proporsi lapangan kerja informal sektor non-pertanian selama tahun 2015 sampai dengan 2017 berkisar di angka 43 persen dan pada tahun 2018 mengalami sedikit kenaikan ke angka 44 persen (Tabel 1). Berdasarkan provinsi, DKI Jakarta merupakan provinsi dengan proporsi lapangan kerja informal terendah. Jika dibandingkan dengan beberapa negara ASEAN, proporsi tenaga kerja yang bekerja pada sektor informal non pertanian di Indonesia pada tahun 2017 lebih tinggi daripada Thailand, Vietnam, Brunei Daruslam, dan Myanmar (Worldbank, 2019).

Terdapat dua aliran dalam menjelaskan hubungan antara proporsi sektor informal dan pertumbuhan ekonomi. Aliran pertama menyebutkan bahwa sektor informal yang besar cenderung berhubungan dengan pertumbuhan ekonomi yang rendah. Sedangkan aliran kedua menyebutkan bahwa sektor informal yang besar cenderung berhubungan dengan pertumbuhan ekonomi yang tinggi. Sarte (2000) menyebutkan bahwa besarnya proporsi sektor informal berhubungan dengan pertumbuhan ekonomi yang rendah dalam dua cara. Pertama, regulasi yang terlalu berlebihan/ketat dapat meningkatkan sektor informal yang pada akhirnya mengakibatkan pertumbuhan ekonomi yang rendah. Kedua, sektor informal yang besar dapat mengurangi pendapatan pemerintah dari pajak sehingga membatasi kemampuan pemerintah dalam membiayai pelayanan kesehatan, pendidikan, infrastruktur yang berujung kepada rendahnya pertumbuhan ekonomi. Loayza (1997) mengungkapkan bahwa di negara-negara Amerika Latin, perkembangan sektor informal dapat mengguncang pertumbuhan ekonomi melalui inefisiensi pemanfaatan layanan publik. Hal tersebut juga searah dengan hasil penelitian Johnson et al. (1997) yang menyimpulkan bahwa terdapat hubungan negatif antara pertumbuhan ekonomi dengan sektor informal.

Selain studi makro, beberapa studi mikro menunjukkan bahwa sektor informal dapat menghambat pertumbuhan ekonomi. De Soto (1989) menyebutkan bahwa biasanya sektor perekonomian informal mampunyai skala kecil yang menyebabkannya beroperasi pada skala yang tidak efisien yang akhirnya mengurangi pertumbuhan ekonomi. Sejalan dengan penelitian tersebut, Raj dan Seethamma (2007) menyimpulkan bahwa sektor usaha informal yang beroperasi di Kerala, India hanya dapat memproduksi 48 persen dari kapasitas produksi potensial mereka. Benjamin dan Mbaye (2010) serta Byiers (2009) juga menghasilkan kesimpulan yang serupa pada saat meneliti usaha informal di negara-negara di Afrika.

Akan tetapi, beberapa peneliti berpendapat bahwa proporsi sektor informal berpengaruh positif terhadap pertumbuhan ekonomi. Usaha sektor informal mempekerjakan penduduk yang 
berketerampilan atau berpendidikan rendah, dengan menggunakan kapital yang lebih kecil daripada usaha formal, dapat meningkatkan perekonomian di negara-negara yang mempunyai proporsi sektor informal yang cukup besar (D'Erasmo dan Boedo, 2011). Penelitian Duarte (2014) di Spanyol menyimpulkan bahwa sektor informal merupakan komplemen dari sektor formal, alih-alih sebagai kompetitor. Sehingga upaya menurunkan ukuran sektor informal dapat menghambat pertumbuhan ekonomi. Sedangkan Eliat dan Zinnes (2002) menyimpulkan bahwa hubungan antara pertumbuhan ekonomi dengan sektor informal diduga tidak linear. Elgin dan Birinci (2015) menyimpulkan bahwa pada saat proporsi sektor informal kecil atau besar maka pertumbuhan ekonomi akan rendah. Sedangkan pada saat proporsi sektor informal menengah, maka pertumbuhan ekonomi akan tinggi. Hal tersebut menunjukkan bahwa hubungan antara sektor informal dan pertumbuhan ekonomi berbentuk huruf $\mathbf{U}$ terbalik.

Penelitian ini bertujuan untuk mempelajari hubungan antara sektor informal dengan pertumbuhan ekonomi dan diharapkan dapat memberikan input dalam strategi untuk mencapai pertumbuhan ekonomi yang optimal. Hasil dan kesimpulan pada penelitian sebelumnya belum tentu berlaku juga di Indonesia mengingat struktur perekonomian Indonesia yang berbeda dari negara lain. Hubungan antara sektor informal dengan pertumbuhan ekonomi penting untuk diteliti karena kebijakan yang yang salah dapat berakibat buruk pada perekonomian.

\section{METODE}

Hasil penelitian empiris mengenai hubungan antara sektor informal dengan pertumbuhan ekonomi sangat bergantung metode yang digunakan untuk mengestimasi proporsi sektor informal. Metode satu dan yang lain dapat menghasilkan kesimpulan ke arah yang berbeda dan cukup sulit diperbandingkan antar satu metode dengan metode yang lainnya (Duarte, 2014). Penelitian ini menggunakan data sekunder yang berasal dari BPS. Proporsi sektor informal didekati dengan proporsi penduduk usia 15 tahun keatas yang bekerja di sektor informal yang bersumber dari Survei Angkatan Kerja Nasional (Sakernas) bulan Agustus/November tahun 2005 sampai dengan tahun 2018. Yang dimaksud pekerja sektor informal dalam penelitian ini adalah mereka yang mempunyai pekerjaan utama dengan status berusaha sendiri, berusaha dibantu buruh tidak tetap/tak dibayar, pekerja bebas, atau pekerja keluarga/tak dibayar. Sedangkan pertumbuhan ekonomi didekati dengan laju pertumbuhan PDRB per provinsi tahun 2005 sampai dengan tahun 2018. Untuk melihat hubungan antara pertumbuhan ekonomi dengan sektor informal, penulis menggunakan diagram pencar. Sedangkan untuk melihat apakah hubungan tersebut berbentuk huruf $\mathbf{U}$ terbalik atau tidak, penulis menggunakan koefisien pada model persamaan regresi. Model regresi yang dibentuk dalam penelitian ini yaitu :

$$
\text { Growth }=\beta_{0}+\beta_{1} \text { Informal }+\beta_{2}(\text { Informal })^{2}+\varepsilon
$$

\footnotetext{
Growth : laju pertumbuhan PDRB provinsi

Informal : proporsi jumlah penduduk usia 15 tahun keatas yang bekerja di sektor informal di setiap provinsi

$\boldsymbol{\varepsilon}$

: error
}

\section{HASIL DAN PEMBAHASAN}

Berdasarkan Gambar 1, diketahui bahwa laju pertumbuhan PDB Indonesia mengalami peningkatan sejak tahun 2001 dan mengalami puncaknya pada tahun 2007. Krisis subprime mortgage di Amerika Serikat nampaknya berdampak pada perekonomian Indonesia sehingga mengakibatkan penurunan laju pertumbuhan PDB pada tahun 2008-2009 dan kembali pulih 
pada tahun 2010. Semenjak tahun 2011 sampai dengan tahun 2015 laju pertumbuhan PDB Indonesia mempunyai tren yang menurun. Pada tahun 2016 sampai 2018 laju pertumbuhan PDB Indonesia kembali meningkat walaupun tidak terlalu signifikan.

Gambar 1. Laju Pertumbuhan PDB Indonesia Tahun 2001-2018 (atas dasar harga konstan)

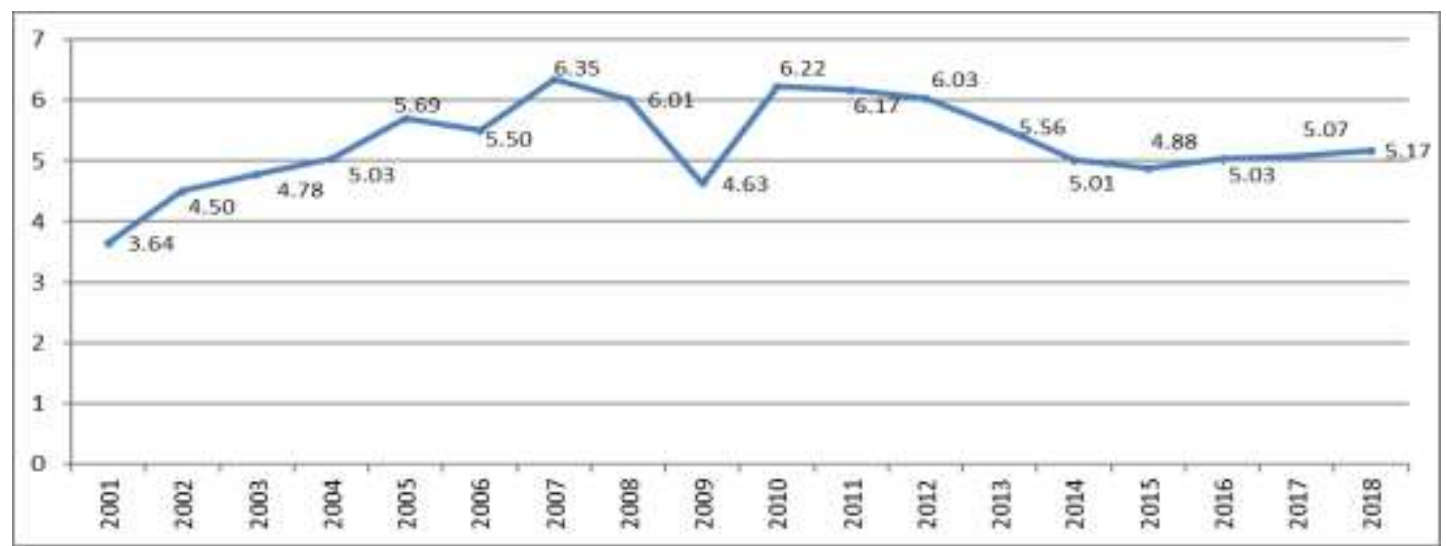

Sumber: BPS, 2019 (diolah)

Secara rata-rata, laju pertumbuhan PDRB selama tahun 2005-2018 di Indonesia bagian barat (provinsi di Pulau Jawa, Sumatera, dan Bali) lebih rendah daripada Indonesia bagian timur (provinsi di Pulau Kallimantan, Nusa Tenggara, Maluku, Sulawesi, dan Papua). Hal tersebut disebabkan karena PDRB Indonesia bagian barat relatif lebih tinggi daripada Indonesia bagian timur, sehingga laju pertumbuhan PDRB-nya akan cenderung lebih rendah. Laju pertumbuhan PDRB selama tahun 2005-2018 di sebagian besar provinsi di Indonesia tidak sampai bernilai negatif kecuali di provinsi Aceh, Riau, NTB, Kalimantan Timur, dan Papua Barat. Selain itu, laju pertumbuhan PDRB di Aceh, Papua, dan Papua Barat tergolong sangat fluktuatif dibandingkan dengan provinsi lainnya. Hal tersebut dimungkinkan karena daerah tersebut tergolong daerah rawan konflik sehingga dapat menghambat investasi yang mengakibatkan perlambatan pertumbuhan ekonomi.

Secara umum, sebagian besar provinsi di Indonesia mengalami penurunan proporsi penduduk berusia 15 tahun ke atas yang bekerja di sektor informal selama tahun 2005-2018. Terdapat 5 provinsi yang selama periode tersebut mempunyai proporsi penduduk berusia 15 tahun ke atas yang bekerja di sektor informal yang cenderung stagnan, yaitu Provinsi Riau, Kep. Riau, DKI Jakarta, Bangka Belitung, dan Papua Barat. Khusus untuk DKI Jakarta dan Kepulauan Riau, stagnansi kemungkinan terjadi karena proporsi sektor informal yang memang sudah cukup rendah dibandingkan provinsi yang lain (sekitar 30 persen), sehingga penurunannya tidak sepesat provinsi lain. Walaupun terdapat indikasi penurunan proporsi sektor informal, sebagian besar provinsi di Indonesia masih mempunyai proporsi sektor informal di atas 60 persen pada tahun 2018.

Secara rata-rata, proporsi penduduk berusia 15 tahun ke atas yang bekerja di sektor informal selama tahun 2005-2018 di Indonesia bagian barat (provinsi di Pulau Jawa, Sumatera, dan Bali) lebih rendah daripada Indonesia bagian timur (provinsi di Pulau Kallimantan, Nusa Tenggara, Maluku, Sulawesi, dan Papua). Walaupun perbedaannya relatif tidak terlalu besar $(59,21$ persen berbanding 68,87 persen), hal tersebut mengindikasikan bahwa terdapat ketimpangan perekonomian antara Indonesia bagian barat dan timur. 
Gambar 2. Hubungan Sektor Informal dan Pertumbuhan Ekonomi di Indonesia

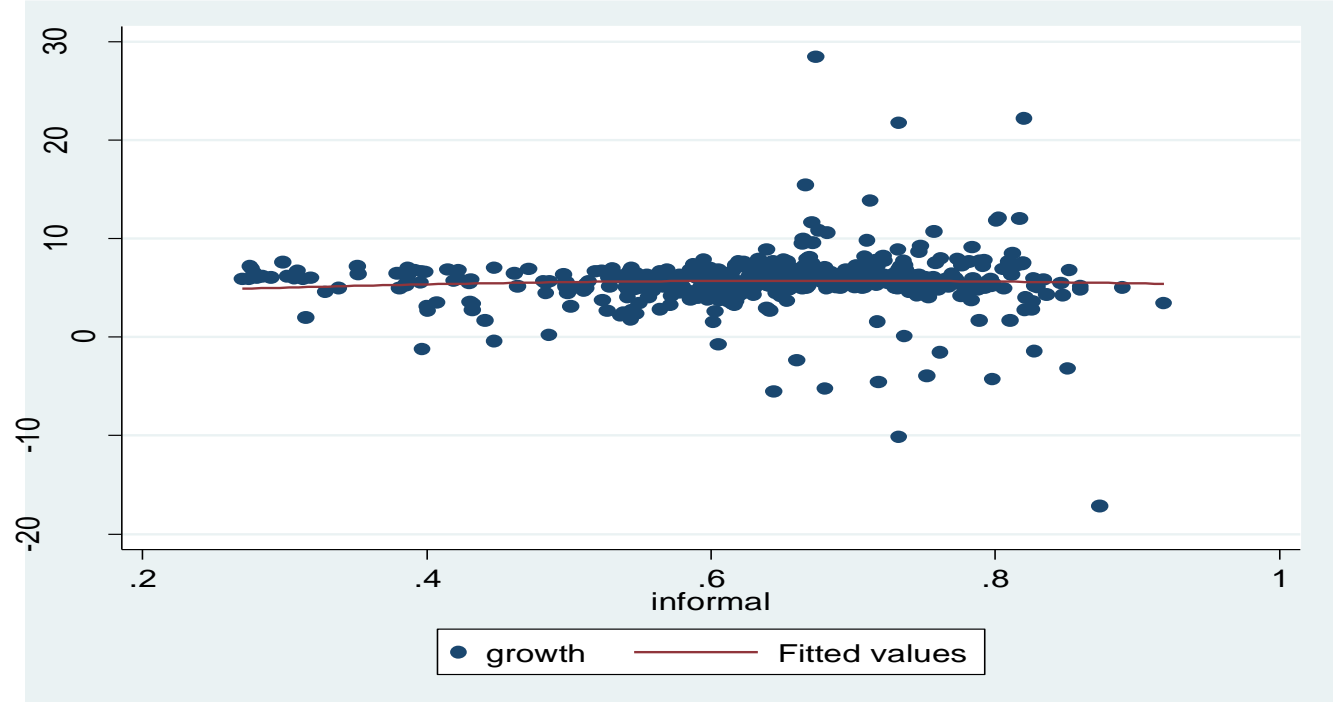

Berdasarkan Gambar 2 diketahui bahwa belum terlihat secara jelas hubungan antara proporsi sektor informal dengan laju pertumbuhan PDRB di Indonesia. Baik provinsi yang memiliki proporsi sektor informal besar maupun kecil, laju pertumbuhan PDRB berada pada kisaran 5,66 persen. Selanjutnya penulis membagi Indonesia menjadi dua wilayah, yaitu wilayah barat yang terdiri dari provinsi yang ada di Pulau Sumatera, Jawa, dan Bali, serta wilayah timur yang terdiri dari provinsi yang ada di Pulau Kalimantan, Nusa Tenggara, Sulawesi, Maluku, dan Papua. Pembagian ini didasarkan atas besar kecilnya PDRB di tiap provinsi, dimana Indonesia di wilayah barat cenderung memiliki PDRB yang lebih tinggi daripada wilayah timur.

Gambar 3a. Hubungan Sektor Informal dan Pertumbuhan Ekonomi di Indonesia Bagian Barat (Sumatera, Jawa, dan Bali)

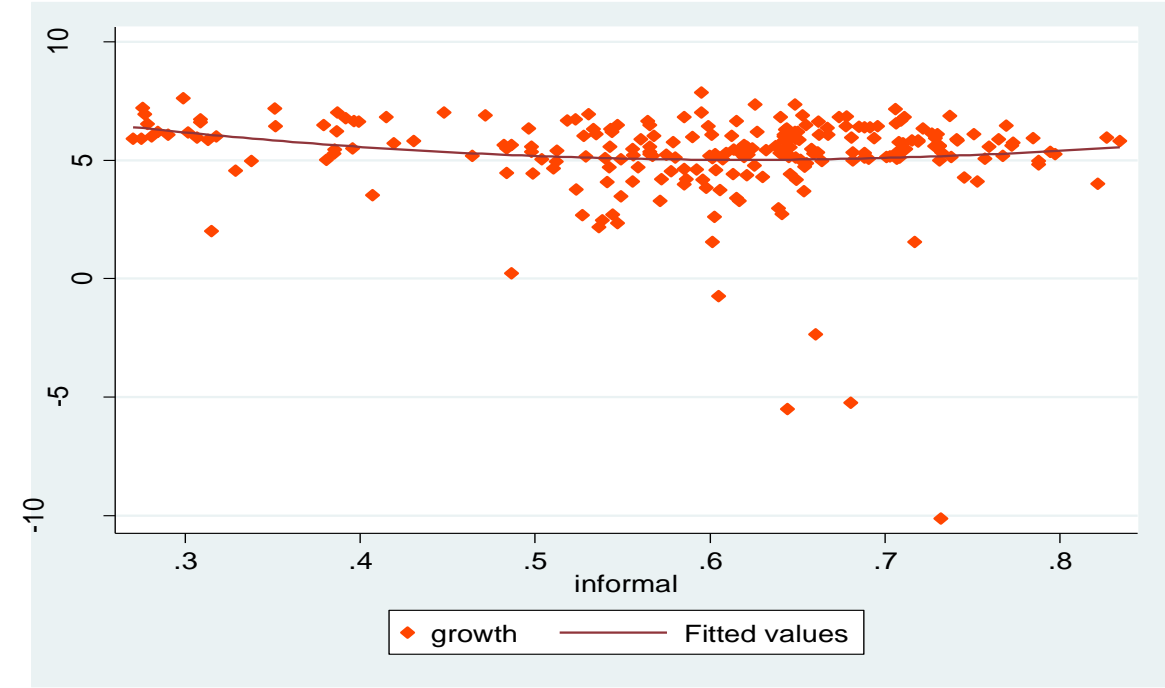


Gambar 3b. Hubungan Sektor Informal dan Pertumbuhan Ekonomi di Indonesia Bagian Timur (Kalimantan, Nusa Tenggara, Sulawesi, Maluku, dan Papua)

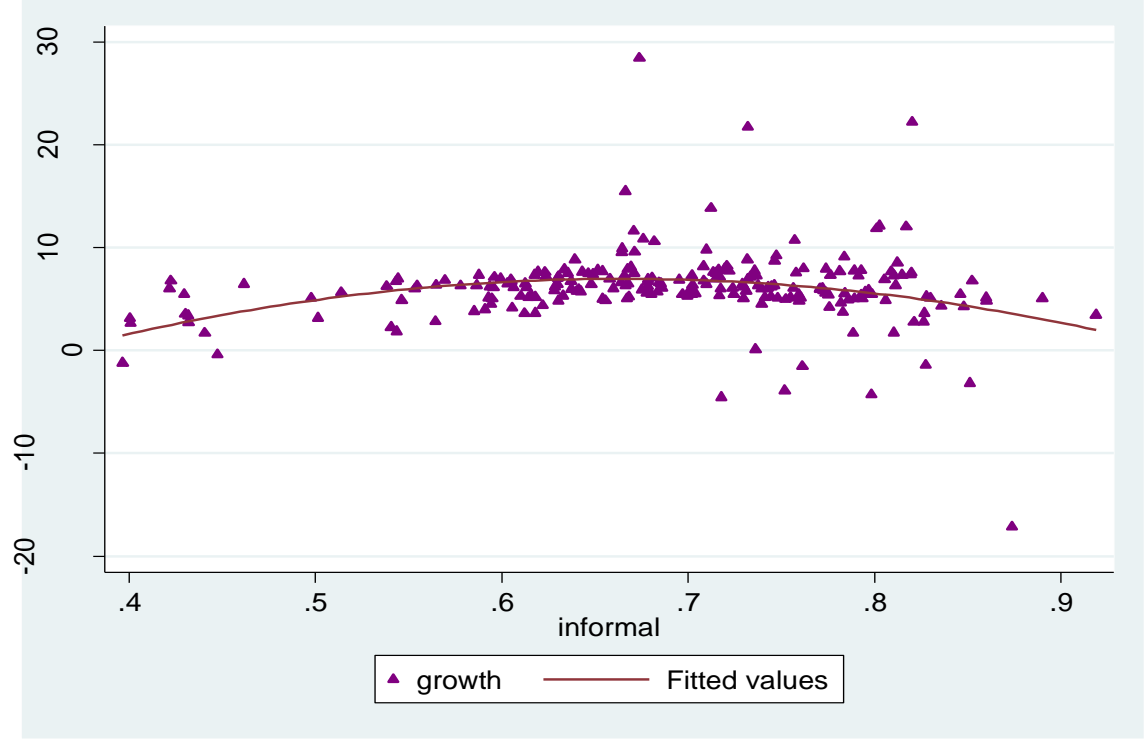

Hubungan antara antara proporsi sektor informal dengan laju pertumbuhan PDRB di Indonesia wilayah barat cenderung berbentuk huruf $\mathbf{U}$ (Gambar 3a). Hal ini menunjukkan bahwa pada saat proporsi sektor informal kecil atau besar maka pertumbuhan ekonomi akan tinggi. Sedangkan pada saat proporsi sektor informal menengah, maka pertumbuhan ekonomi akan cenderung rendah.

Sedangkan hubungan antara antara proporsi sektor informal dengan laju pertumbuhan PDRB di Indonesia wilayah timur cenderung berbentuk huruf $\mathbf{U}$ terbalik (Gambar 3b). Hal ini sesuai dengan kesimpulan Elgin dan Birinci (2015) yang menyebutkan bahwa pada saat proporsi sektor informal kecil atau besar maka pertumbuhan ekonomi akan rendah. Sedangkan pada saat proporsi sektor informal menengah, maka pertumbuhan ekonomi akan cenderung tinggi. Menurut Elgin dan Birinci (2015), proporsi sektor informal yang besar berhubungan dengan pertumbuhan ekonomi yang tinggi di daerah maju. Sedangkan di daerah yang masih berkembang, proporsi sektor informal yang besar berhubungan dengan pertumbuhan ekonomi yang rendah.

Tabel 2. Koefisien Regresi antara Proporsi Sektor Informal dengan Pertumbuhan Ekonomi

\begin{tabular}{|l|r|r|r|r|r|r|}
\hline \multirow{2}{*}{ Growth $(\mathrm{Y})$} & \multicolumn{2}{|c|}{ Indonesia } & \multicolumn{2}{c|}{ Bagian Barat } & \multicolumn{2}{c|}{ Bagian Timur } \\
\cline { 2 - 7 } & \multicolumn{1}{|c|}{ Coef. } & \multicolumn{1}{c|}{$\mathrm{P}>|\mathrm{t}|$} & \multicolumn{1}{c|}{ Coef. } & $\mathrm{P}>|\mathrm{t}|$ & \multicolumn{1}{c|}{ Coef. } & \multicolumn{1}{c|}{$\mathrm{P}>|\mathrm{t}|$} \\
\hline Informal $\left(\beta_{1}\right)$ & 6.931 & 0.434 & -14.128 & 0.002 & 102.108 & 0.000 \\
\hline informal_sqr $\left(\beta_{2}\right)$ & -5.180 & 0.527 & 11.432 & 0.011 & -76.873 & 0.000 \\
\hline cons. & 3.424 & 0.133 & 9.390 & 0.000 & -26.924 & 0.000 \\
\hline
\end{tabular}

Bentuk kurva dari hubungan antara proporsi sektor informal dengan pertumbuhan ekonomi juga dapat diketahui dari nilai koefisien $\left(\beta_{1}\right)$ dan $\left(\beta_{2}\right)$. Berdasarkan koefisien hasil regresi pada Tabel 2 diketahui bahwa hubungan antara antara proporsi sektor informal dengan pertumbuhan ekonomi di wilayah Indonesia bagian barat berbentuk huruf $\mathbf{U}$. Hal tersebut diketahui berdasarkan nilai koefisien $\left(\beta_{1}\right)$ yang bertanda negatif dan koefisien $\left(\beta_{2}\right)$ yang 
bertanda positif. Sedangkan hubungan antara antara proporsi sektor informal dengan pertumbuhan ekonomi di wilayah Indonesia bagian timur berbentuk huruf $\mathbf{U}$ terbalik. Hal tersebut diketahui berdasarkan nilai koefisien $\left(\beta_{1}\right)$ yang bertanda positif dan koefisien $\left(\beta_{2}\right)$ yang bertanda negatif.

Kesimpulan yang didapatkan dari penelitian ini masih bersifat awal dengan menggunakan pendekatan yang sederhana. Penelitian selanjutnya diharapkan untuk dapat menggali lebih dalam hubungan antara proporsi sektor informal dengan pertumbuhan ekonomi di Indonesia dengan menggunakan metode pendekatan yang lain, diantaranya Currency demand approach atau energy consumption approach sebagai pendekatan untuk mengestimasi proporsi sektor informal.

\section{PENUTUP}

Penelitian ini bertujuan untuk mengetahui hubungan antara proporsi sektor informal dan pertumbuhan ekonomi di Indonesia. Berdasarkan analisa diagram pencar dan koefisien regresi disimpulkan bahwa hubungan antara sektor informal dan pertumbuhan ekonomi berbentuk huruf $\mathbf{U}$ di wilayah Indonesia bagian barat dan berbentuk huruf $\mathbf{U}$ terbalik di wilayah Indonesia bagian timur.

Perbedaan pola hubungan antara proporsi sektor informal dengan pertumbuhan ekonomi di tiap wilayah di Indonesia menunjukkan bahwa kebijakan untuk mencapai pertumbuhan ekonomi optimal tidak bisa disamaratakan di semua wilayah di Indonesia. Keberadaan sektor informal, yang identik dengan produktifitas rendah dan kurang efisien, sering dianggap menghambat pertumbuhan ekonomi. Kebijakan untuk menurunkan sektor informal mungkin akan berdampak positif kepada pertumbuhan ekonomi di Indonesia bagian barat. Akan tetapi, kebijakan yang serupa bisa jadi berdampak negatif terhadap pertumbuhan ekonomi di Indonesia bagian timur. Hal tersebut dapat disebabkan karena masih cukup besarnya proporsi sektor informal, belum siapnya sarana-prasarana, serta faktor institusional yang belum memadai di Indonesia bagian timur.

\section{DAFTAR PUSTAKA}

Badan Pusat Statistik. (2006). Keadaan Angkatan Kerja November 2005. Jakarta: BPS. Badan Pusat Statistik. (2007). Keadaan Angkatan Kerja Agustus 2006. Jakarta: BPS. Badan Pusat Statistik. (2008). Keadaan Angkatan Kerja Agustus 2007. Jakarta: BPS. Badan Pusat Statistik. (2009). Keadaan Angkatan Kerja Agustus 2008. Jakarta: BPS. Badan Pusat Statistik. (2010). Keadaan Angkatan Kerja Agustus 2009. Jakarta: BPS. Badan Pusat Statistik. (2011). Keadaan Angkatan Kerja Agustus 2010. Jakarta: BPS. Badan Pusat Statistik. (2012). Keadaan Angkatan Kerja Agustus 2011. Jakarta: BPS. Badan Pusat Statistik. (2013). Keadaan Angkatan Kerja Agustus 2012. Jakarta: BPS. Badan Pusat Statistik. (2014). Keadaan Angkatan Kerja Agustus 2013. Jakarta: BPS. Badan Pusat Statistik. (2015). Keadaan Angkatan Kerja Agustus 2014. Jakarta: BPS. Badan Pusat Statistik. (2016). Keadaan Angkatan Kerja Agustus 2015. Jakarta: BPS. Badan Pusat Statistik. (2017). Keadaan Angkatan Kerja Agustus 2016. Jakarta: BPS. Badan Pusat Statistik. (2018). Keadaan Angkatan Kerja Agustus 2017. Jakarta: BPS. Badan Pusat Statistik. (2019). Keadaan Angkatan Kerja Agustus 2018. Jakarta: BPS. Badan Pusat Statistik. (2019). Laju Pertumbuhan Produk Domestik Regional Bruto Atas

Dasar Harga Konstan 2000 Menurut Propinsi, 2000-2013. diakses pada 15 Oktober 2019, dari https://www.bps.go.id/dynamictable/2009/06/29/1596/laju-pertumbuhan-produkdomestik-regional-bruto-atas-dasar-harga-konstan-2000-menurut-provinsi-2000-2013- 
persen-.html

Badan Pusat Statistik. (2019). Laju Pertumbuhan Produk Domestik Regional Bruto Atas Dasar Harga Konstan 2010 Menurut Propinsi, 2010-2018. diakses pada 15 Oktober 2019, dari https://www.bps.go.id/dynamictable/2015/10/07/961/-seri-2010-laju-pertumbuhanproduk-domestik-regional-bruto-atas-dasar-harga-konstan-2010-menurut-provinsi-20102018-persen-.html

Benjamin, Nancy C., and A. Mbaye Ahmadou. (2010). Informallity, Productivity, and Enforcement in West Africa: A Firm Level Analysis. Working Paper 100, IPC.

Byiers, Bruce (2009). Informality In Mozambique: Characteristics, Performance, and Policy Isuue. Mimeo, USAID.

Derasmo, Pablo N., and Herman J. Moscoso Boedo. (2012). Financial Structure, Informality and Development. Journal of Monetary Economics (59): 286-302.

De Soto, Hernando (1989). The Other Path: The Invisible Revolution in the Third world. New York, Harper Row.

Duarte, Pablo. (2014). The Relationship Between GDP and the Size of the Informal Economy: Empirical Evidence for Spain. Working Paper 127, Leipzig.

Elgin, Ceyhun, and Serdar Birinci. (2016). Growth and Informality: A Comperehensive Panel Data Analysis. Journal of Applied Economics (19): 271-292.

Eliat, Yair, and Clifford Zinnes. (2000). The Evolution of the Shadow Economy in Transition Countries: Friend or Foe? A Policy Perspective. World Development (30): 1233-1254.

ILO. (2004). Statistical Definition of Informal Employment: Guidelines Endorsed by the 17th International Conference of Labour Statisticians. Geneva: Switzerland.

Johnson, Simon, Daniel Kaufman, and Andrei Shleifer (1997). The Unoficial Economy in Transition, Brookings Papers in Economic Activity (2): 159-221.

Loayza, Norman V. (1997). The Economics of the Informal Sector: A Simple Model and Some Empirical Evidence from Latin America. Carnegie-Rochester Conference Series on Public Policy (45): 129-162.

Pitoyo, Agus Joko. (2007). Dinamika Sektor Infornal di Indonesia: Prospek, Perkembangan, dan Kedudukannya dalam Sistem Ekonomi Makro. Populasi, 18 (2) : 129-146.

Portes, A., M. Castells, and L. Benton. (1989). World Underneath: The Origin, Dynamics, and Effects of the Informal Economy. Baltimore, Johns Hopkins.

Sarte, Pierre-Daniel G. (2000). Informality and Rent-Seeking Bereaucracies in a Model of Long Run Growth. Journal of Monetary Economics (46): 173-197.

World Bank. (2019). Informal Employment (\% of total non-agricultural employment). diakses pada 15 Oktober 2019, dari https://data.worldbank.org/indicator/SL.ISV.IFRM.ZS 